\begin{tabular}{|l|l|l||}
\hline \multicolumn{2}{|c|}{ PublisherInfo } \\
\hline \hline PublisherName & $:$ & BioMed Central \\
\hline \hline PublisherLocation & $:$ & London \\
\hline \hline PublisherImprintName & $:$ & BioMed Central \\
\hline \hline
\end{tabular}

\title{
Bugs in flies
}

\begin{tabular}{|l|l|l||}
\hline \multicolumn{2}{|c|}{ ArticleInfo } \\
\hline \hline ArticleID & $:$ & 4275 \\
\hline \hline ArticleDOI & $:$ & $10.1186 /$ gb-spotlight-20011212-01 \\
\hline \hline ArticleCitationID & $:$ & spotlight-20011212-01 \\
\hline \hline ArticleSequenceNumber & $:$ & 346 \\
\hline \hline ArticleCategory & $:$ & Research news \\
\hline ArticleFirstPage & $:$ & 1 \\
\hline \hline ArticleLastPage & $:$ & 2 \\
\hline \hline & $:$ & RegistrationDate : 2001-12-12 \\
ArticleHistory & $:$ & OnlineDate \\
\hline \hline ArticleCopyright & $:$ & BioMed Central Ltd2001 \\
\hline \hline ArticleGrants & $:$ & \\
\hline \hline ArticleContext & $:$ & 130592211 \\
\hline \hline
\end{tabular}




\section{Jonathan B Weitzman}

Email: jonathanweitzman@hotmail.com

The mechanisms underlying the innate immune system are highly conserved from flies to mammals. In the December 18 Proceedings of the National Academy of Sciences, Irving et al. describe a genomewide screen for genes induced in Drosophila following infection with bacteria or fungi (Proc Natl Acad Sci USA 2001, 98:15119-15124). They performed oligonucleotide-array gene-profiling analysis on material from flies inoculated with Gram-negative or Gram-positive bacteria or with the fungi Beauveria bassiani. Induced genes included several encoding well-characterized anti-microbial peptides. Genes for components of the Toll and Imd signaling pathways were induced, such as dorsal, cactus and relish. A large number of genes for proteases and protease-inhibitors were expressed; understanding their roles in immune defense will require further characterization. Additional genes from different functional classes not previously implicated in the immune response were also upregulated. Nearly half of the immuneinduced genes are of unknown function, providing many new clues into innate immunity.

\section{References}

1. Phylogenetic perspectives in innate immunity.

2. Proceedings of the National Academy of Sciences, [http://www.pnas.org] 